\title{
Local food diversification of foxtail millet (Setaria italica) cultivars in West Sulawesi, Indonesia: A case study of diversity and local culture
}

\author{
RAMLAH $^{1}$, MARCIA BUNGA PABENDON ${ }^{2}$, BUDI SETIADI DARYONO ${ }^{3, \bullet}$ \\ ${ }^{1}$ Graduate Program in Biology, Faculty of Biology, Faculty of Biology, Universitas Gadjah Mada. Jl. Teknika Selatan, Sleman 55281, Yogyakarta, \\ Indonesia \\ ${ }^{2}$ Indonesian Cereals Research Institute. Jl. Dr. Ratulangi No. 274, Maros 90512, South Sulawesi, Indonesia \\ ${ }^{3}$ Laboratory of Genetics and Breeding, Faculty of Biology, Universitas Gadjah Mada. Jl. Teknika Selatan, Sleman 55281, Yogyakarta, Indonesia. \\ Tel.: +62-274-580839, Fax.: +62-274-6492355, `email: bs_daryono@mail.ugm.ac.id, ramlahganis@ gmail.com
}

Manuscript received: 19 July 2019. Revision accepted: 5 December 2019.

\begin{abstract}
Ramlah, Pabendon MB, Daryono BS. 2020. Local food diversification of foxtail millet (Setaria italica) cultivars in West Sulawesi, Indonesia: A case study of diversity and local culture. Biodiversitas 21: 67-73. Foxtail millet (Setaria italica (L.) P.Beauv.) is one of the non-rice cereal crops that has long been domesticated in the world, including West Sulawesi-Indonesia as an alternative food crop instead of rice on local culture. Traditional millet cultivars may become an indispensable part of the local culture and traditions of millet-growing people across Asia over many generations. The existence of this germplasm in West Sulawesi Province, Indonesia has been observed morphologically and showed a close relationship with local culture. A total of six traditional millet cultivars (Tarreang) with different morphological characteristics have been found in this region and still preserved sustainably by the local farmers along with their local culture and traditions. The tradition of Sayyang pattu'duq may become a good example of this relationship. In this tradition, some traditional food is made by the local people like porridge tarreang, jelly tarreang, buras tarreang, jepa golla mamea, jepa anjoroi, dodol tarreang, also widely presented and used as a symbol in important ceremonies, such as celebrations in the month of Muharram, completed Al-Qur'an for children, weddings, births or show the baby's. This information may be useful as guidance for conservation and millet breeding programs in the future.
\end{abstract}

Keywords: Foxtail millet, Indonesia, local culture, Tarreang, West Sulawesi

\section{INTRODUCTION}

Sulawesi is one of the five largest islands in Indonesia, located in the east of Kalimantan, which is filled with the Makassar Strait and in the west of Maluku Islands. Biogeographically, Sulawesi is one of the largest and most important islands in the Wallacea region. Volcanic deposits and smaller rainfall from Kalimantan cause soil types to become more unique, so that flora that is able to grow adapts to dry areas. These conditions make Sulawesi one of the richest regions that will contribute to life after Papua and Kalimantan (Sunarko 2013). The biological potential of Sulawesi's plant diversity has not been fully studied, approved by various new scientific discoveries by botanists, both those supporting new records and new types (new species) (Pitopang et al. 2008).

The type of Indonesian agroecology is very diverse; this can be seen by the diversity of regions, topography, land, water availability and climate that have formed plants to grow and adapt to specific locations. Cultivars that have good tolerance to local conditions are known as local cultivars (landrace) (Ramlah et al. 2017). Local food crop (germplasm) is a very important asset so it must be preserved, as well as an effort to find, collect and research types of food crops, to secure it as a source of genes in the millet breeding programs in the future (Rais 2004).

One potential cereal with good prospects to be developed in West Sulawesi, Indonesia is foxtail millet
(Setaria italica (L.) P. Beauv.). Foxtail millet is one of the non rice food crops that have long been domesticated in the world including in West Sulawesi Province, Indonesia as an alternative food crop, mainly because of its ability to grow and adapt to both tropical and sub-tropical regions of India, China, Asia, North Africa and America (Kole 2017). Foxtail millet is one type of cereal plant that has very good potential as an alternative food crop in terms of nutritional value, a major source of energy, protein and has high nutritive value, comparable to major cereals such as wheat, rice, and maize (Saleh et al. 2013). This plant has good nutrition, carbohydrate, protein, fat, and rich in fiber (Bandyopadhyay et al. 2017). Aside from being a source of carbohydrates, millet can be developed as a functional food source because it has a low glycemic index (Thathola et al. 2011), the high anti-oxidant content (Sharma et al. 2015), even potentially as an anti-cancer (Saleh et al. 2013) and relative tolerance to drought or salinity stresses (Widyawan et al. 2018). Evaluation of nutritive values and antinutrients showed that foxtail millet from Papua, Indonesia is potential to be used as feedstuff, and used as a corn substitution in poultry feed (Tirajoh 2015). This plant is one of the important cereals that is used as food and feed with high nutritional quality and contains a number of bioactive compounds that have many benefits.

In West Sulawesi, foxtail millet known as Tarreang, has several local cultivars, many of which are planted and processed by the local people into a variety of traditional 
food. Alimuddin (2014) reported that in addition to food, in West Sulawesi tarreang is also used as a symbol in important ceremonies, such as ceremony in the month of Muharram, Maulid Nabi Muhammad SAW, weddings, and show the baby's birth.

The study of the multi-disciplinary surveys must be conducted with local farmers regarding their nutrition, seed availability, economy, climate, and other crops in the cropping system for millet breeding in the future. An intensive study of the diversity of local germplasm will be the most important task of breeders to support the strategic method for development of millet breeding (Newmaster et al. 2013). However, the complex interactions between millet diversity, diversification of local food, and cultural practices, including local traditions have not been revealed. This study focused to explore and assess the interaction between millet diversity, food diversification to the local culture in West Sulawesi Province, Indonesia. Consequently, the complex interaction between that diversity, food diversification and their local cultures would be better understood.

In this study, several issues related to the complex interaction between millet diversity, food diversification, and local culture are discussed. Hence, the objectives of this study were to collected traditional millet cultivars from West Sulawesi Province Indonesia, characterize the germplasm based on morphological traits, and gathered information from farmers concerning the meaning of the name, origin, and special use of cultivars related to the local culture and tradition.

\section{MATERIALS AND METHODS}

This study was initiated by collecting samples from three regions of West Sulawesi Province, Indonesia, i.e. Polewali Mandar, Majene and Mamuju Districts (Figure 1). The coordinate sampling locations where traditional millet cultivars were collected; Balanipa, Polewali Mandar District ( $3^{\circ} 30^{\prime} 17.5^{\prime}$ ' S; $119^{\circ} 05^{\prime} 04.7^{\prime \prime}$ E) (i.e. Balanipa, Lego, Lambanan villages); Tamerodo, Majene District ( $3^{\circ}$ 12'57.0' S; $118^{\circ} 50^{\prime} 26.2^{\prime}$ ' E) (i.e. Tamerodo Village); and Tapalang, Mamuju District (2 $54^{\prime} 29.2^{\prime \prime} \mathrm{S} ; 118^{\circ} 53^{\prime}$ $12.7^{\prime}$ ' E) (i.e. Taan, Kasambang villages). Samples collection was conducted from August-December 2018 by random sampling method (Mursyidin et al., 2017). The trip started with down the road along the beach in Balanipa Sub-district on the Polewali Mandar District then continued to Tammerodo Sendana Sub-district on the Majene District, then continued to Tapalang Sub-district on the Mamuju District.

In each Sub-district, seed samples were collected directly from the millet field (Figure 2) when the farmers have harvested fresh seeds and identified each cultivar based on their appearance. Those samples also collected from bags of stored grain (old seeds). At the same time, farmers have interviewed to gather information about the origin, the name, and the special uses of those cultivars, for example for mixed foodstuff, occasions to use millet products, and used as a symbol in important ceremonies, etc. All of the collected data were arranged and analyzed by the following procedure of Miswarti et al. (2012). Each millet cultivars were observed for their morphological characters such as hypocotyl color, folius leaf color, bone stem color, plant pigmentation, stem color, panicle density, form of growth, leaf color, leaf surface, seed color, seed shape, panicle branch, hairy panicle, grain length, and grain width based on the foxtail millet (S. italica L.) descriptors of International Board for Plant Genetic Resources (IBPGR 1985) with some modification.

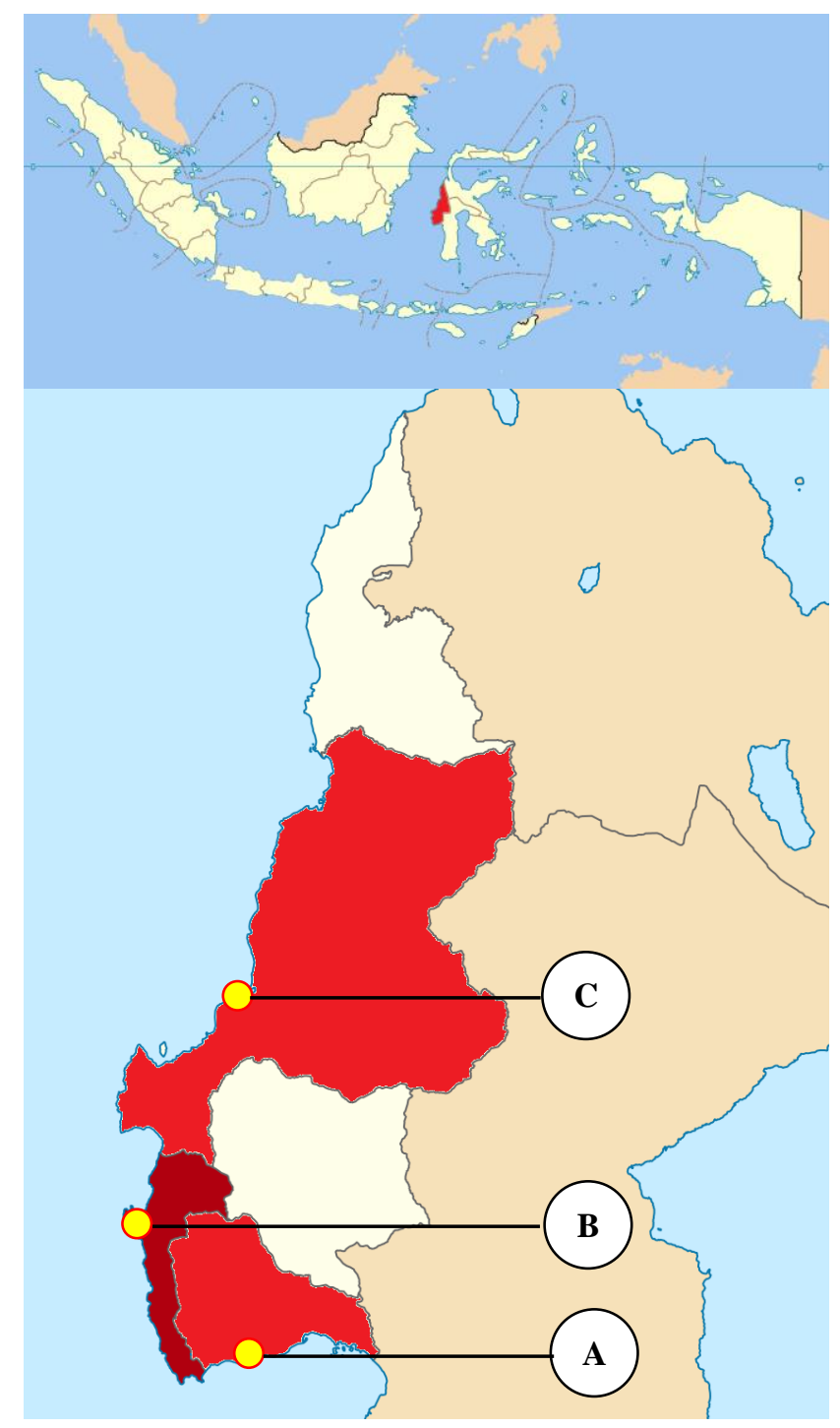

Figure 1. Sampling location where traditional foxtail millet cultivars were collected in three sub-districts of three districts in West Sulawesi, Indonesia: A. Polewali-Mandar, B. Majene, C. Mamuju. 


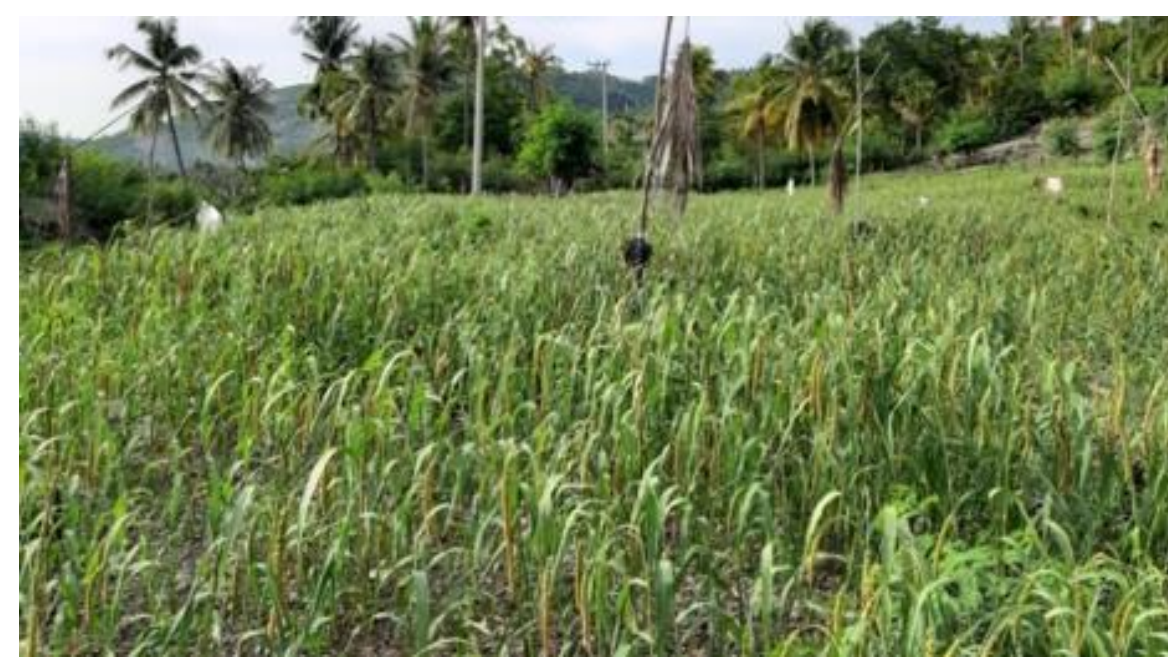

A

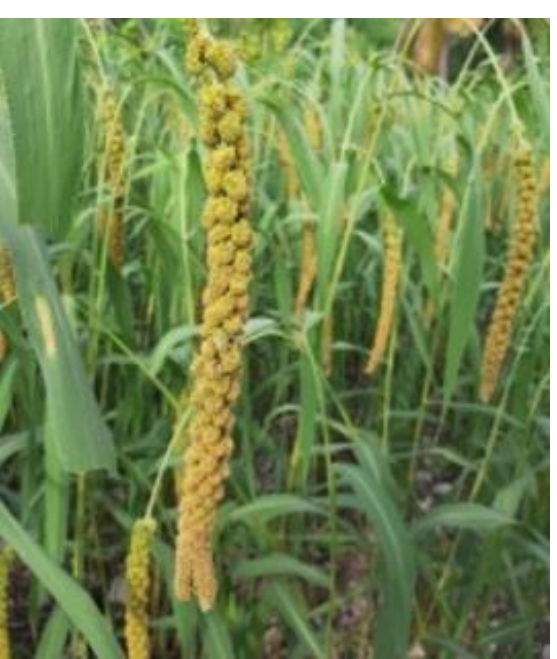

B

Figure 2. A. Millet farm of the farmers; B. Panicle of millet in West Sulawesi Province, Indonesia

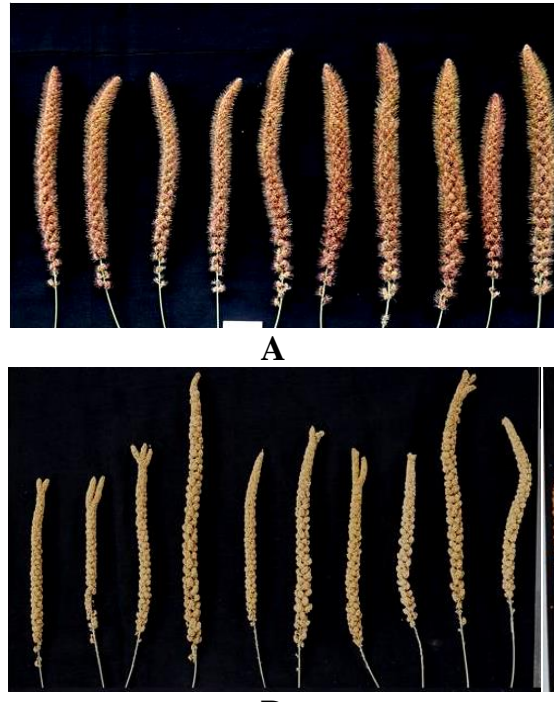

D

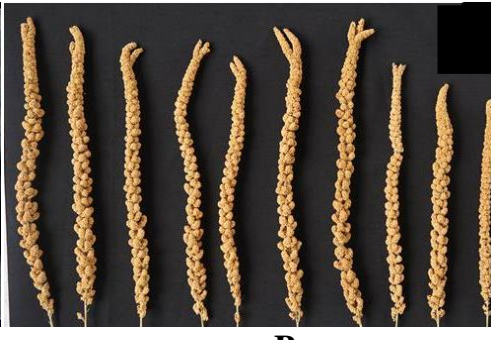

B

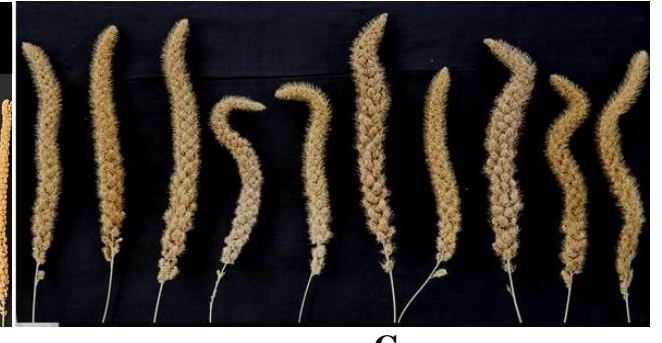

C

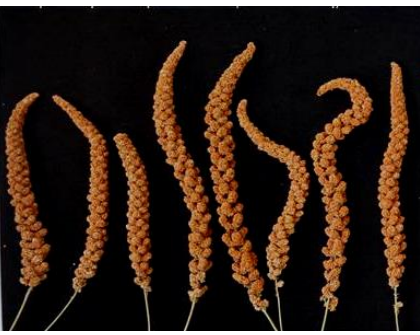

$\mathbf{E}$

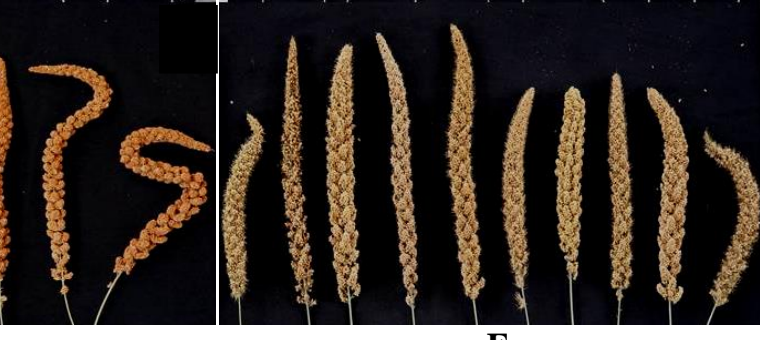

$\mathbf{F}$

Figure 3. Six local foxtail millet cultivars in West Sulawesi, Indonesia; A. Sikola'; B. Minna'; C. Mapute; D. Lasse'; E. Bulawang; F. Lelamung

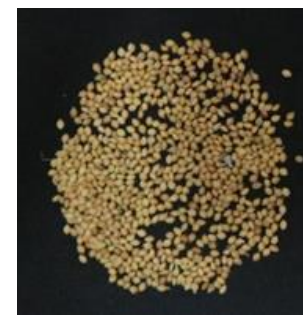

A

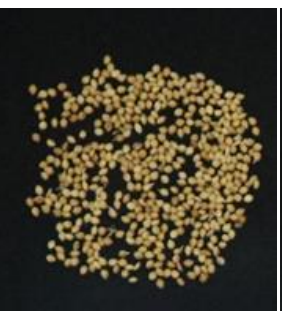

B

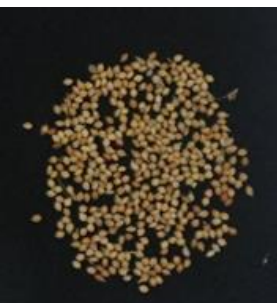

C

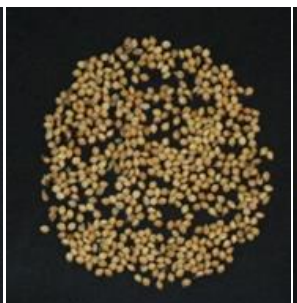

D

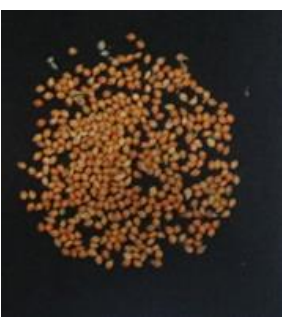

$\mathbf{E}$

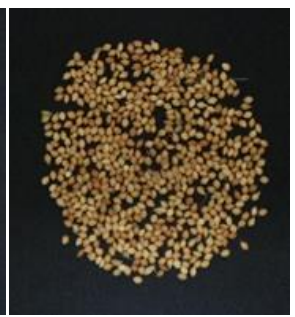

$\mathbf{F}$

Figure 4. Grain futures of six (6) traditional millet cultivars collected from three regions of West Sulawesi Province, Indonesia. Name of each cultivar are indicated in Table 1. A. Sikola'; B. Minna'; C. Mapute; D. Lasse'; E. Bulawang; F. Lelamung 


\section{RESULTS AND DISCUSSION}

\section{Results}

A total of six traditional millets were collected from three regions of West Sulawesi Province, Indonesia. These cultivars have a unique name, origins, and morphological characteristics; Sikola', Minna', Mapute, Lasse', Bulawang, and Lelamung as presented in Table 1. The Result of morphological observation showed variation among 6 millet were in their panicles, especially the panicle density, panicle branch, hairy panicle (Figure 3), and seed color (Figure 4).

Most of the millet cultivars show a unique characteristic of the panicle branch, and color of the grain, indicating the variation of millet cultivars. In table 1 , it can be seen that the millet in this area has variety of morphological characters. The tip of panicle was branch (Minna' and Lasse') and others were not branched (Sikola', Mapute, Bulawang, and Lelamung). Some cultivars had short-hairy panicle (Minna', Lasse', and Bulawang), medium (Lelamung), and long size (Sikola' and Mapute). There was also variety in density of panicle i.e., medium, spongy, and compact. These six millet cultivars have a small seed size, the length ranges from 1.5 to $2 \mathrm{~mm}$, the width is $1-1.5 \mathrm{~mm}$. The shape of the seeds is the same, which is rather oval, with a seed color that varies from cream, brown cream, to brick red (Figure 4).

Results on interviews with farmers and local communities revealed that in West Sulawesi Province, millet is known by local people as Tarreang. Six millet cultivars were used together by the local people to make various kinds of traditional foods. Some of those traditional foods are given in Table 2 and Figure 5. From Table 2, the hairy and non-hairy millets have been used extensively in those traditional foods.

Tarreang had been planted for a long time from many previous generations. Millet was harvested twice or two times in a year. The distribution area of the plant is around the mountains, which are directly adjacent to the sea. Its ability to grow in dry areas, makes this plant still grow well even though in areas with poor soil nutrients. For irrigation, local farmers only rely on the rainy season. The harvest from the land can be stored for quite a long time (5-10 years) in the local people's storage warehouse (Figure 6). Millet seeds are highly favored by birds which are the main pests in garden before harvesting. Apart from being used for daily needs, the harvest is also sold to local traditional markets at a good price of IDR.22.000,00IDR.28,000.00/Kg.

Table 2. Traditional foods which are made by local people of West Sulawesi Province, Indonesia from traditional millet cultivars, both hairy and non-hairy millets

\begin{tabular}{ll}
\hline Name of traditional foods & Local cultivars \\
\hline Apang tarreang & Grain of all the six cultivars \\
Atupe tarreang & Grain of all the six cultivars \\
Bagea tarreang & Grain of all the six cultivars \\
Baje' tarreang & Grain of all the six cultivars \\
Balundake tarreang & Grain of all the six cultivars \\
Bolu paranggi & Grain of all the six cultivars \\
Bolu tarreang & Grain of all the six cultivars \\
Buras tarreang & Grain of all the six cultivars \\
Chips/kasippi tarreang & Grain of all the six cultivars \\
Dodol mapute & Grain of all the six cultivars \\
Dodol tarreang & Grain of all the six cultivars \\
Gogos tarreang & Grain of all the six cultivars \\
Golla kambu & Grain of all the six cultivars \\
Jelly tarreang & Grain of all the six cultivars \\
Jepa anjoroi & Grain of all the six cultivars \\
Jepa golla mamea & Grain of all the six cultivars \\
Jepa tarreang & Grain of all the six cultivars \\
Kareppe & Grain of all the six cultivars \\
Katirimandi & Grain of all the six cultivars \\
Porridge tarreang/Uleq-uleq & Grain of all the six cultivars \\
Putu golla mamea & Grain of all the six cultivars \\
Putu golla pasir & Grain of all the six cultivars \\
Putu tarreang & Grain of all the six cultivars \\
Sokkol tarreang & Grain of all the six cultivars \\
\hline
\end{tabular}

Table 1. Millet cultivars collected and their morphological characteristics

\begin{tabular}{|c|c|c|c|c|c|c|}
\hline \multirow[b]{2}{*}{ Village } & \multicolumn{6}{|c|}{ Morphological characters of millet cultivars } \\
\hline & Balanipa & Lego & Lambanan & Tammerodo & Taan & Kasambang \\
\hline Sub-district & Balanipa & Balanipa & Balanipa & Tammerodo & Tapalang & Tapalang \\
\hline District & Polewali Mandar & Polewali Mandar & Polewali Mandar & Majene & Mamuju & Mamuju \\
\hline Hypocotyl color & Green & Green & Green & Green & Purple & Green \\
\hline Folius leaf color & Green & Green & Green & Green & Purple & Green \\
\hline Bone stem color & Green & Green & Green & Green & Purple & Green \\
\hline Plant pigmentation & Green & Green & Green & Green & Purple & Green \\
\hline Stem color & Dark green & Dark green & Dark green & Dark green & Light green & Dark green \\
\hline Panicle density & Compact & Compact & Compact & Medium & Medium & Spongy \\
\hline Form of growth & Upright & Upright & Upright & Upright & Upright & Upright \\
\hline Leaf color & Green & Green & Green & Green & Purplish green & Green \\
\hline Leaf surface & Rough & Rough & Rough & Rough & Rough & Rough \\
\hline Seed color & Yellowish beige & Beige & Brick red & Beige & Beige & Beige \\
\hline Seed shape & Rather oval & Rather oval & Rather oval & Rather oval & Rather oval & Rather oval \\
\hline Panicle branch & Yes & Yes & No & No & No & No \\
\hline Hairy panicle & Short & Short & Short & Long & Long & Medium \\
\hline Grain length (mm) & $1.5 \mathrm{~mm}$ & $1.5 \mathrm{~mm}$ & $2 \mathrm{~mm}$ & $2 \mathrm{~mm}$ & $2 \mathrm{~mm}$ & $2 \mathrm{~mm}$ \\
\hline Grain width (mm) & $1 \mathrm{~mm}$ & $1 \mathrm{~mm}$ & $1.5 \mathrm{~mm}$ & $1.5 \mathrm{~mm}$ & $1.5 \mathrm{~mm}$ & $1.5 \mathrm{~mm}$ \\
\hline
\end{tabular}




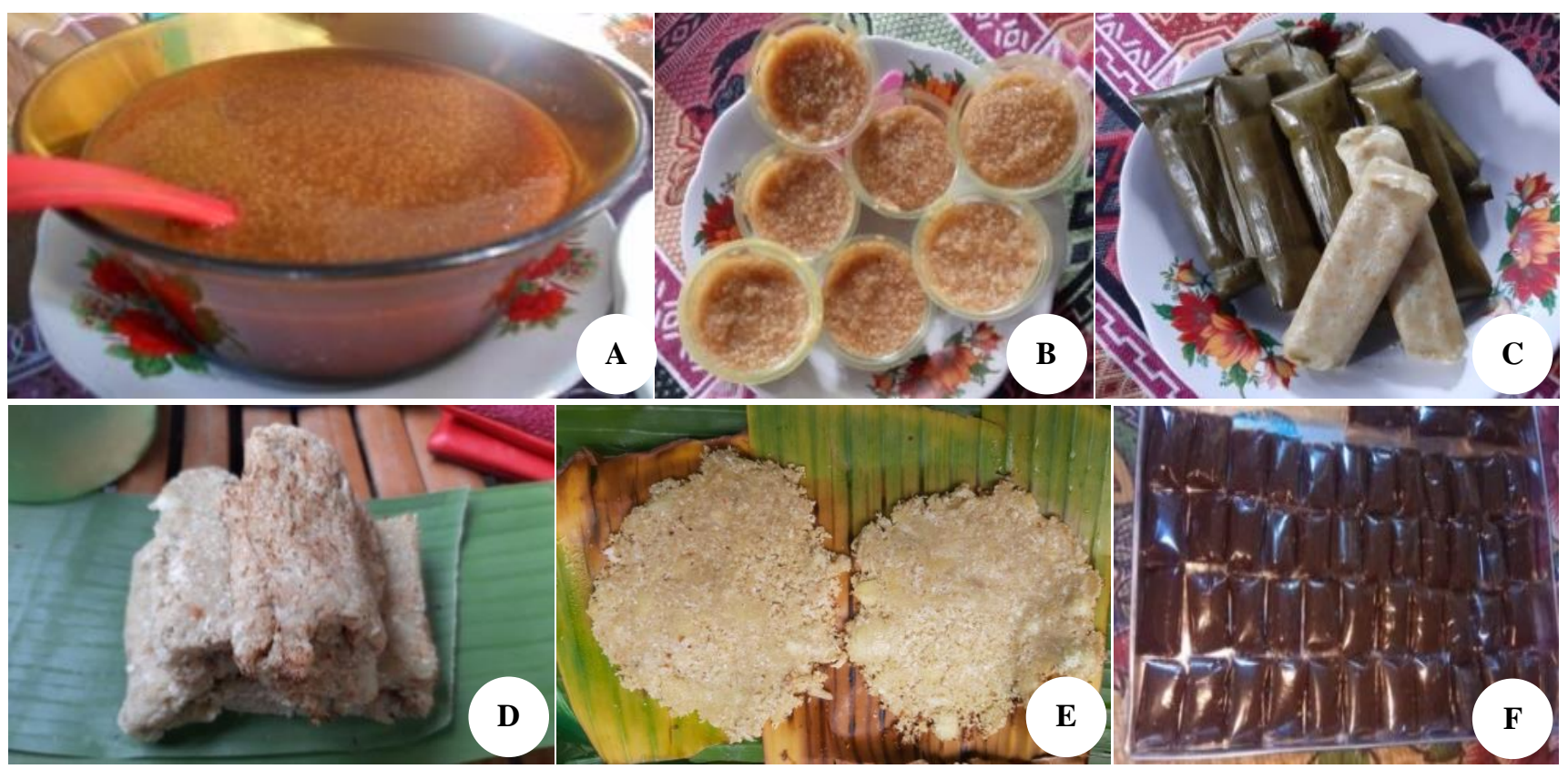

Figure 5. Some of those traditional foods which are made by local people of West Sulawesi, Indonesia from Setaria italica. A. Porridge tarreang/Uleq-uleq, B. Jelly tarreang, C. Buras tarreang, D. Jepa golla mamea, E. Jepa anjoroi, F. Dodol tarreang

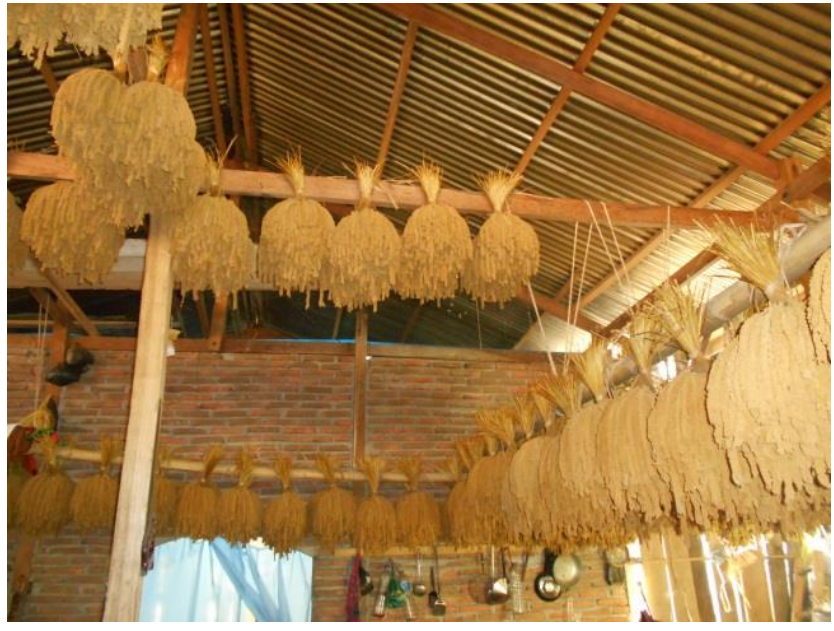

Figure 6. Storage of millet in farmer's house in West Sulawesi, Indonesia

Based on historical reviews as well, besides being processed into food for rice substitutes. Tarreang has also become an icon of local food in this area. Tarreang is the local food for daily meals and has the meaning or symbol behind its use. For example in the month of Muharram, the Maulid of the Prophet Muhammad coupled with local traditions Sayyang Pattu'duq, for children who have been completed learning of the Al-Qur'an (Figure 7). Sayyang Pattu'duq is a cultural heritage. Sayyang has a meaning as a horse and Pattu'duq means dancing, so that when combined, the meaning is a dancing horse. In these traditions, a horse will be ridden by local people with a Bodo suit. The horse is decorated with a variety of

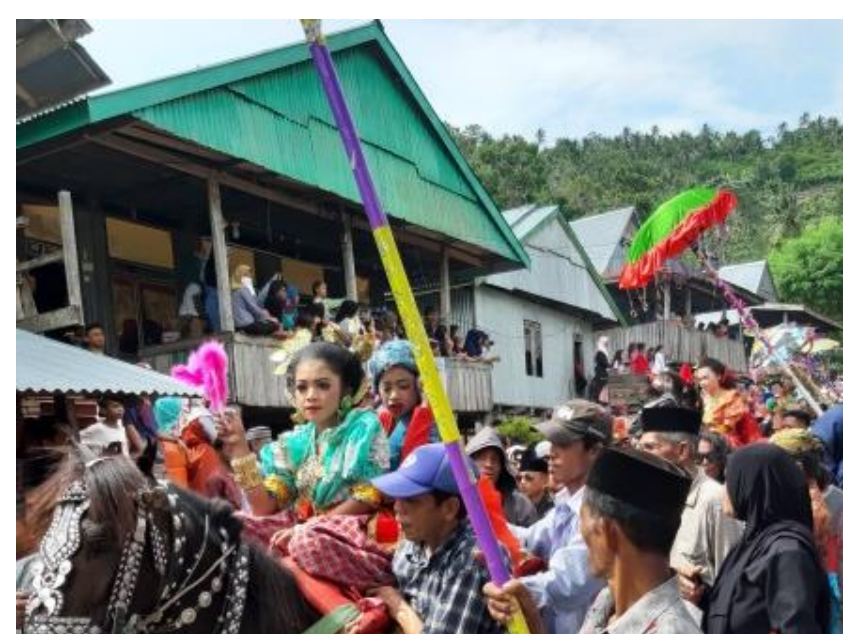

Figure 7. Local culture, tradition of Maulid Nabi Muhammad SAW - Sayyang Pattu'duq in West Sulawesi, Indonesia

accessories like a king's and queen mount during the royal era which is then in a rollicking around the villages. In Sayyang Pattu'duq celebration, the time when tarreang becomes very popular, and expensive, usually when it becomes buras, 'ule-uleq' or porridge. Other celebrations that also often use tarreang are wedding, births or showing new born baby's. The people believe that tarreang can bring a lot of fortune, many children, abundant catches or harvests for the local community. Besides being processed into porridge, tarreang can also be various forms of local food which is processed using coconut milk, such as Sokkol tarreang, Jelly tarreang, Buras tarreang, Jepa golla mamea, Jepa anjoroi, and Dodol tarreang (Figure 6). By 
the local people, a lot of seeds in panicle of millet used as a symbol of hope, to be given an abundance of fortune.

\section{Discussion}

In other parts of Indonesian, Yulita et al. (2018) reported that other than in Buru Island, millet also can be found in several regions of Indonesia including Sulawesi, Maluku, East Nusa Tenggara, and some parts of Java. The utilization of millet as an alternative crop was limited due to their small seeds as well as low seed yield. Induced mutation is an effort to improve the potency of millet as an alternative food through genetic improvement. In other cereal such as rice, Mursyidin et al. (2017) reported that forty (40) traditional rice (Oryza sativa L.) cultivars of South Kalimantan Province, Indonesia with different morphological characteristics have been found in this country, still preserved sustainable by the local farmers along with their local culture and tradition 'Wadai41'. In 'Wadai41' tradition, the local people make some traditional foods from local rice, and use some of the local rice as basic ingredients. This indicates that local cultivars such as millet in West Sulawesi, Indonesia can be used to support food security through diversification of local food which is closely related to local culture and traditions. Also to maintain and preserve the local germplasm of millet in the future.

Millet is an important food source because of its ability to grow under adverse weather conditions (Amadou et al. 2011). Yulita et al. (2018) reported that two variants of millet were recorded from Buru Island, red and yellow variant each referring to the color of their seeds. Acheampong et al. (1984) reported that the grain of foxtail millet has advantages that are very profitable, they can be stored for a long time, even if they can last for more than 10 years without physical damage or without an attack of seed lice.

In addition to food, Alimuddin (2014) reported that millet or tarreang in West Sulawesi-Indonesia was used in important ceremonies. Not its function as food, but the properties possessed by tarreang plants. Tarreang by local communities in West Sulawesi is classified as fertile plants. Fertile means it has many fruits. One panicle of tarreang, has thousands of tarreang ears. This trait is used as 'ussul' or symbolism. So, it is often used by local people in ceremonies, such as weddings, and show the newborn baby's. Tarreang was also used by local fishermen in hunting fish in the sea. Thus, we can infer that the existence of millet diversity is closely related to the local culture of this region. Fitriani et al. (2013) reported that millet also can be used to made macaroni products. Traditional millet-based foods and beverages and their processing techniques are highlighted by Amadou et al. (2011). Martins et al. (2018) reported that millets in Brazil have a high potential as food for humans because they are gluten-free, higher in dietary fiber content than rice, similar in lipid content to maize and higher content of essential amino acids than other traditional cereals, such as wheat and rye.

This study emphasizes the importance of the complex interaction between foxtail millet diversity, food diversification, and local culture. The study results provide preliminary information about the existence and diversity of millet as a functional food source with their local culture and traditions. Comprehensive characterization provides strong basis conservation of germplasm and crop improvement through selection of superior varieties of millet. This information may be useful as guidance for millet breeding programs in the future.

\section{ACKNOWLEDGEMENTS}

This research was funded by Indonesia Endowment Fund for Education (LPDP), Republic of Indonesia for 2018-2019 number PBI-01475/LPDP/2017, and the publication was supported by RTA grant No:2988/UN1/DITLIT/DIT-LIT/LT/2019.

\section{REFERENCES}

Acheampong E, Anishetty NM, and William JT. 1984. A world survey of sorghum and millet germplasm. International Board for Plant Genetic Resources. IBPGR Secretariat, Rome.

Alimuddin MR. 2014. Tarreang culinary and proposals. AIJ (Alliance of Independent Journalists) Indonesia. http://bejobe.aji.or.id/read/berita/ 18/Kuliner-Tarreang-dan-Ussulannya.html [Indonesian]

Amadou I, Gbadamosi OS, and Le GW. 2011. Millet-based traditional processed foods and beverages-a review. Cereal Foods World 56 (3): 115-121.

Bandyopadhyay T, Jaiswal V, Prasad M. 2017. Nutrition potential of foxtail millet in comparison to other millets and major cereals. National Institute of Plant Genome Research (NIPGR). Aruna Asaf Ali Marg, New Delhi, India.

Fitriani, Sugiyono, Purnomo EH. 2013. Development of macaroni products made from mixtures of foxtail millet (Setaria italica L.) flour, Purple Sweet Potato (Ipomoea batatas var. Ayamurasaki) and Wheat (Triticum aestivum L.) Flour. J Pangan. 22 (4): 349-364.

IBPGR. 1985. Descriptors for Setaria italica and S. pumila. International Board for Plant Genetic Resources (IBPGR), Rome, Italy.

Kole C. 2017. The Foxtail Millet Genome. Springer, New Delhi.

Martins AMD, Pessanha KL, Pacheco S, Rodrigues JAS, Carvalho CWP. 2018. Potential use of pearl millet (Pennisetum glaucum (L.) R. Br.) in Brazil: Food security, processing, health benefits and nutritional products. Food Res Intl 109: 175-186.

Miswarti, Tatuhey MD, Oktavia Y. 2012. Exploration and characterization of foxtail millet germplasm (Setaria italica L. Beauv.) in Bengkulu, South Sumatra and West Java Provinces, Indonesia. BPTP, Bengkulu. [Indonesian]

Mursyidin DH, Nazari YA, and Daryono BS. 2017. Short Communication: Tidal swamp rice cultivars of South Kalimantan Province, Indonesia: A case study of diversity and local culture. Biodiversitas 18 (1): 427-432

Newmaster SG, Ragupathy S, Dhivya S, Jijo CJ, Sathishkumar R, and Patel K. 2013. Genomic valorization of the fine-scale classification of small millet landraces in Southern India. Genome. 56: 123-127.

Pitopang R, Khaeruddin I, Tjao A, Burhanuddin IF. 2008. Introduction of common tree types in Sulawesi. Central Sulawesi Provincial Government and Celecence Herbarium. Plant Ecotoxonomy Laboratory, Department of Biology, Universitas Tadulako, Palu, Indonesia.

Rais AS. 2004. Exploration of food crop germplasm in West Kalimantan Province, Indonesia. Buletin Plasma Nutfah 10 (1): 23-27.

Ramlah, Aziz IR, Muthiadin C, Masri M, Mustami MK, and Pabendon MB. 2017. Genetic diversity of local maize germplasm of Tana Toraja South Sulawesi using SSR (Simple Sequence Repeat) Markers. Agricultural Science 2 (3): 144-153.

Saleh ASM, Zhang Q, Chen J, and Shun Q. 2013. Millet grains: nutritional quality, processing, and potential health benefits. Comp Rev Food Sci Food Saf 12: 281-295. 
Sharma S, Saxena DC, Riar CS. 2015. Antioxidant activity, total phenolics, flavonoids and antinutritional characteristic of germinated foxtail millet (Setaria italica). Cogent Food Agric1: 1081728 DOI: 10.1080/23311932.2015.1081728.

Sunarko T. 2013. Sulawesi corridor-caring NKRI expedition and conserving Indonesia's nature. PT. Jepe Press Media Utama, Jakarta. [Indonesian]

Thathola A, Srivastava S, and Singh G. 2011. Effect of foxtail millet (Setaria italica) supplementation on serum glucose, serum lipids, and glycosylated hemoglobin in type 2 diabetics. Diabetologia Croatica 40: $23-28$.
Tirajoh S. 2015. Utilization of foxtail millet (Setaria italica L.) from Papua as a substitute for maize. Wartazoa. 25 (3): 117-124.

Widayawan MH, Khumaida N, Kitashiba H, Nishio T, Ardie SW. 2018. Optimization of dot-blot SNP analysis for the detection of drought or salinity stress associated marker in foxtail millet (Setaria italica L.). SABRAO J Breed Genet 50 (1): 72-84.

Yulita KS, and Ridwan. 2018. Molecular characterization of induced mutation of jewawut (Setaria italic ssp. italica) from Buru Island, Indonesia using SRAP. Biodiversitas 19 (2): 1160-1168. 